\title{
The Impact of Voluntary Risk Management Disclosure, The Composition of the Board of Independent Commissioners Toward Firm Value on Indonesian Property ,Real Estate and Building Construction Companies
}

\author{
Almubarokah Tri Robayany $^{*} \quad$ Yvonne Augustine \\ Trisakti Universrity, Faculty of Economic and Business Jl. Kyai Tapa No 1 Grogol , Indonesia
}

\begin{abstract}
This study aims to examine the impact of voluntary disclosure of non financial risk management, and the composition of the board of independent commissioners toward firm value. The population of this study is the property, real estate and building construction sector companies listed on the Indonesia Stock Exchange (IDX) using Purposive Sampling. Data analysis method is multiple regression methods. The results of the study are voluntary non financial risk management disclosure has negatively significant impact to firm value while the composition of independent commissioners does not affect the value of the Company.
\end{abstract}

Keywords: Voluntary risk management disclosures, composition of independent commissioners, Firm Value DOI: $10.7176 / \mathrm{JESD} / 10-8-19$

Publication date: April $30^{\text {th }} 2019$

\section{Introduction}

In general, Risk Management has enabled companies to make better decisions at various levels, from the level of the overall strategy of the company, to operational decision making. With the ability to anticipate various risks, a company becomes more agile both in minimizing negative effects and reaching opportunities that arise. This makes Risk Management a strategic capability that will be greatly needed by various companies, especially in free trade environments such as the MEA (CRMS Indonesia, 2016).

However, information about the risks of non-financial management provided does not emphasize the existence of this information and therefore is incomplete in disclosing non-financial risks compared to financial management risk information disclosures (Lajili and Zeghal, 2005). The Lack of information on non-financial risks may mislead investors in the process of making their investment decisions. According to Cabedo and Tirado (2004), investors make investment decisions or withdraw their investments by evaluating the returns and the level of risk they will invest. If an investor fails to identify the true key risk factors of the company, investors cannot assess the true level of risk of these companies. This will then lead investors to make the wrong investment decisions that can end up with large losses or disasters to investors.

Determination of a risk disclosure can be done when the disclosure informs the reader about an opportunity, prospect, or danger, and a threat that can affect the company in the future or that has had an impact on the company in the past or the management of the company regarding opportunities and the threat (Linsley and Shrives, 2006).

Prior studies discovered that investors agree the existence of more risk management disclosure would help them in their portfolio investment decisions (Solomon et al., 2000, 2011) which in turn could lead to a reduction in the risk of investing in the reporting firm (Orens and Lybaerts, 2007). It is still unclear whether such wariness with regards to the negative impact of more risk management information disclosure among firms is valid. The issue on the usefulness of voluntary risk management information is vital to be investigated since even prior research regarding the association between voluntary disclosure and FV are still showing mixed results (such as Al-Akra and Ali, 2012; Uyar and Kilic, 2012; Hassanet al., 2009; Bokpin, 2013; Qiu et al., 2014).

Hence, the controversy between investors and firms regarding voluntary risk management disclosure (VRMD) motivates the aim of this study, which is to examine the effects of non-financial risk disclosure towards firm value (FV).

Nowadays, the supervisory body places more emphasis on financial risk management disclosure through the enforcement of PSAK 60 (revised 2013); while information on non-financial risk is less emphasized in current guidelines such as the National Committee on Governance (2006), the Financial Services Authority Number 51 /POJK.03/2017 which only requires companies to disclose non-financial risk management information without specific details. Because this study has provided evidence on the significance of non-financial risk management disclosures in the capital market, this study can be useful for regulatory agencies to develop more detailed guidelines on future disclosure of non-financial risk management and to better understanding of the problems faced by entrepreneurs or companies that can affect the economic problem in general.

\section{2 . Institutional Background}

Regulatory agencies in Indonesia requires the existence of information related to risk reported by the company in 
the annual report. PSAK 60 (Revised 2010) concerning Financial Instruments: Disclosures, and Decree of Chairperson of BAPEPAM-LK Number KEP-431 / BL / 2012 concerning Submission of Annual Report of Issuers or Public Companies, states that information can be used by users from financial statements to evaluate types and the level of risk and certain of financial instruments must be disclosed. Based on these two rules, all financial and non-financial companies are required to submit risk information in their annual report, but the broad minimum disclosure regarding risk management is not regulated in the two provisions. Non-financial companies are not bound by rules regarding minimum risk management practices that must be disclosed.

Furthermore, the Indonesian Financial Services Authority with POJK Number 51 / POJK.03 / 2017 which obliges public companies and Issuers in Indonesia to submit sustainable financial reports in their business activities with the principles of social and environmental risk management, while it does not regulate detailed risk management disclosures. The looseness of ERM disclosure provisions in non-financial companies causes these companies to tend to pay less attention to the completeness of ERM disclosure instruments.

Non-financial reporting standards in Indonesian companies following the same trend, with different interests in the disclosure and qualitative reporting there are gaps between large companies and smaller companies. Important negligence related to detailed ownership data from insiders, weak director \& commissioner remuneration data and very limited information regarding audit and non-audit fees obtained by the audit company. Detailed corporate governance statements issued by existing voluntary laws and those required by large companies to choose most of what they don't like, provide lip service according to requirements to meet the minimum complaint standards. The OJK CG Roadmap reflects changes to the regime, with plans to introduce a regime that was approved or explained in 2015.

While Indonesia benefited from its split-board structure, with the board of commissioners (board) overseeing the executive management board, following the Dutch corporate law model, the definition of independence for the purpose of escaping as independent. Members of the Board of Commissioners are weak. This makes a lot of room for manipulation by the executive board and / or controlling shareholders.

An unusual, but apparently useful, feature of the Indonesian audit committee system is the appointment of independent professionals from outside the board of commissioners to the audit committee. This fulfills practical needs, namely the general lack of accounting expertise among commissioners. That said, some audit committees in Indonesia can be said to be truly independent because the board of commissioners themselves are not truly independent: the composition usually reflects proportional shareholder ownership

Politic and economic dynamic in the world will never end. To anticipate this, companies can take various strategic steps and mitigate changes that occur. Therefore, it becomes a demand for companies to prepare themselves for future risks.

Based on the survey result issued by CRMS Indonesia for the year 2018 regarding the benefits of implementing Risk Management base on industry perspective, the successfull implementation of Risk Management often cannot be measured by the company because the impact cannot be immediately felt at that time. Every sector or industry has different perceptions of the functions of the Risk Management process in the company. Based on the number of respondents with the most samples in this survey, overall financial performance is benefited of Risk Management with a percentage of 75.5\%. However, Risk Management is considered not able to provide great benefits for the construction industry, namely $(30 \%)$ in determining the efectiveness of the implementation of Risk Management in the company, instead of leadership and strong commitment from top management.

Many studies have investigated the relationship between corporate governance instruments, such as board tasks, executive compensation, board size and board independence, and firm performance in developed countries for instance, (Coles and Hesterly, 2000;Daltonet al.,1999;Elsayed, 2007;Jensen, 1993;Yermack, 1996). However, in developing countries, some studies have been conducted in recent past to investigate the impact of corporate governance instruments on firm value, such as the study by Arora and Sharma (2016).

This study is to find out the impact of voluntary risk management disclosures in property, real estate and building construction sector companies to Firm Value and this study aims to examine whether the proportions of board independent has any impacts on Firm Value.

\section{Literature Review}

\subsection{Voluntary Risk Management Disclosures}

How much information must be disclosed does not only depend on the expertise of the reader, but also the standards needed. Financial statements are not the only source of information in the decision making process, information and descriptions of corporate governance are also important in making decisions for an investor, therefore companies must disclose information widely and comprehensive.

Disclosure according to Evans stated by Suwardjono (2005) is "supplying information in financial statements, including the statements themselves, the notes to the statements, and the supplementary disclosures associated with the statements. It does not extend to public or private statements made by management or information outside 
the financial statements. "

The types of disclosures implemented by companies are categorized into mandatory disclosure and voluntary disclosure. Mandatory disclosure is a disclosure required by the applicable regulations, in this case the regulations stipulated by the authorized institution. Whereas voluntary disclosure is disclosure that is more than required.

In Indonesia, the provisions of mandatory disclosure are determined by accounting policy makers, namely IAI (Indonesian Institute of Accountants) and OJK (Financial Services Authority). One of the regulations made by OJK is regulation No. VIII. G. 7 based on the Decree of Chairman of Bapepam 11 Number Kep-347 / BL / 2012 on June 25,2012 concerning the presentation and disclosure of the financial statements of issuers or public companies. Whereas IAI made a statement regarding disclosure regulated in PSAK No. 60 (revised 2013). PSAK 60 (2013) Financial Instruments: Disclosures replace SFAS 60 (2010) Financial Instruments: Adjusted disclosures in October 2012. PSAK 60 is IFRS 7 adoption Financial Instrument: Disclosure per effective January 1, 2013.

PSAK 60 (revised 2013) subject to Entity discloses information that enables users of financial statements to evaluate the type and scope of types of risks arising from financial instruments which is exposed by the entity at the end of the reporting period. Disclosure focuses on the risks that arise and how those risks are managed. The provision of qualitative disclosures in the context of quantitative disclosures allows users to relate disclosures so that they understand the overall picture and nature of risk. OJK Regulation (Bapepam-LK No.X K6) or KEP-134 / BL / 2006 concerning the obligation to submit annual reports for issuers or public companies.

According to OJK regulation, risk management is "an explanation of the risks faced by the company and the efforts that have been made to manage these risks, for example: risks caused by fluctuations in exchange rates or interest rates, business competition, raw material supply, state provisions other or international regulations, and government policies ".

\subsection{Voluntary disclosure}

Risk can be defined as uncertainty associated with potential gains and losses (Solomon et al., 2000, p. 449). Linsley and Shrives (2006, p. 389) more specifically defines risk disclosure as any information disclosed to readers about opportunities, prospects, hazards, strands or exposures that have impacted or can impact the company or management in the future. In comparison, financial textbooks usually define 'Risk' as a series of results that arise from decisions that can be given probabilities while 'uncertainty' arises when probabilities cannot be assigned to a set of results (Linsley and Shrives, 2006, p. 338). This broad risk definition was adopted in this study because they comprehensively embraced 'risk' and 'uncertainty'.

Linsley and Shrives (2006) also explain the categorization of risk models by the Institute of Chartered Accountants in England and Wales (ICAEW) (1998) which consists of 5 non-financial risks, namely operational risk, strategic risk ), Integrity Risk, Empowerment Risk, and Information processing and technology Risk. Because the five risks are included in the category division of voluntary disclosure of non-financial risk management, so that with the disclosure of these 5 risks, it is expected to be able to contribute to business instability.

Voluntary disclosure, in the context of globalization of world financial markets, has received considerable attention in the accounting literature in recent years (Healy and Palepu, 2001; Wang et al., 2008). Corporate decisions to communicate more voluntary disclosures may be responses to innovation, globalization, or changes in the business environment and capital markets (Healy and Palepu, 2001).

Efficient Market Hypotheses generally indicate that a firm's value must reflect all available information reported to the public (Ohlson, 1995). Companies may have incentives to disclose more voluntarily information to increase the trust of stakeholders, especially investors, on company performance and prospects (Core, 2001). Previous research has empirically demonstrated that voluntary disclosure positively influences firm value (Amir and Lev, 1996; Al-Akra and Ali, 2012; Uyar and Kilic, 2012; Oliveira et al., 2010; Anamet al., 2011; Vafaei et al., 2011). Amir and Lev (1996) found that when financial information is combined with non-financial information, they show a positive relationship with Corporate Values among US companies. This shows that non-financial information that is generally voluntary is relevant to investors and complements financial information. Voluntary disclosures in their research include strong background information, information about directors, capital market data, product and service information, employee information and research information. Al-Akra and Ali (2012) found that voluntary disclosure has a positive and significant relationship with Company Value.

Some other studies, however, claim otherwise. Hassan et al. (2009), for example, shows that voluntary disclosure has a significant negative impact on FV in the Egyptian capital market. Bokpin (2013) also documented that voluntary disclosure does not have a significant effect either on the market for the book value of equity ratios (MTBR) or price shares on the Ghana stock market. Wang et al. (2013) showed similar results in the Chinese capital market. The results are also supported by recent research from Qiu et al. (2014). Qiu et al. (2014) hypothesize that environmental and social disclosure will display a positive relationship with FV because information communication is believed to provide a competitive advantage to the company. In turn, it will increase the Corporate Value of FV. 


\subsection{Firm Value}

Firm is an organization that seeks profit, the purpose of the company is usually expressed in the form of money. There are two main objectives of the company, namely maximizing profits and maximizing prosperity. The goal of maximizing prosperity is to maximize the value of the company. Understanding the value of the company according to Martono and Harjito (2005: 13), namely "the value of the company is reflected in the stock market value if the company has gone public if it has not gone public, the company value is the value that occurs when the company is sold".

The value of the company according to Keown, et al. (2010:46) is "the market value of outstanding debt and equity securities of the company. The price that the prospective buyer is willing to pay is defined as the market price of the company itself. Company value can be achieved to the maximum if the shareholders hand over the business management matters to people who are competent in their fields, such as managers and commissioners.

Tobin's Q or Q ratio or Q Theory is a ratio or theory which in 1969 was first introduced by James Tobin. James Tobin is an American economist who successfully won a Nobel in economics with his hypothesis, the market value of a company should be the same as the cost of replacing the company's assets so that an equilibrium condition is created.

Tobin's Q formula is the sum of MVE and DEBT divided by the TA where MVE can be searched by multiplying the number of ordinary shares of the company circulating at the end of the year with the closing price at the end of the year, DEBT calculated by means (Total Debt + Inventory - Assets Current) and TA are the book value of the company's total assets.

The above formula has been adjusted to the conditions of financial transactions of company companies in Indonesia. Tobin's q $<1$ Describes that shares are undervalued. In this condition means management has failed to manage company assets, causing low potential investment growth. Tobin's $q=1$ Describes that stocks are in average condition. Means management is stagnant in managing their assets and potential investment growth does not develop. Tobin's q $>1$ describes that the stock is overvalued. Management is successful in managing their company assets.

Previous research also used Tobin Q (TOBIN) as another measurement for FV (Chen et al., 2014; Chi, 2009). TOBIN measures the ratio of market value and reimbursement of company assets. A lower ratio value (between 0 and 1) means that the cost of replacing a company's assets is greater than the value of its shares. This means that the company's shares are undervalued. On the other hand, a ratio greater than 1 indicates that the company's stock is more expensive than the cost of replacing assets, implying that the stock is overvalued. Tobin's value is measured based on equity market value plus liability book value, divided by book value of total assets (Pathan and Faff, 2013; Orenset al., 2009; Chi, 2009; Baek et al., 2004).

Another tool for assessing how the Company Value is market capitalization (MCAP); the background of why using MCAP because it is more accurate in measuring FV. It is because MCAP takes into account the overall market value of a company, while stock prices only measure the value of a company based solely on the price of one stock (Uyar and Kilic, 2012; Anam et al., 2011). We calculate the MCAP by multiplying the total company's shares at the market price.

Hassan et al. (2009) stated that the company's stock price after six months at the end of the financial year can ensure that stock prices have captured all accounting information disclosed by the company's annual report. For this study we use two different periode of reporting to ensure that the market stock price capturing all of accounting information disclosed in the company's annual report and economic factors that might affect the company's stock price.

In addition, previous research found that among many macroeconomic factors, changes in world oil prices were one of the factors that did not significantly affect changes in the share of company prices (Apergis and Miller, 2009; Al-Fayoumi, 2009). Therefore, the assumption that the company's share price at the end of six months after the end of the year has been considered all the economic changes that occur during that period and will provide a fair reflection of $\mathrm{FV}$.

With regard to the book value of equity, taken at the end of the accounting year. Stock price data comes from the IDX database while other financial data comes from financial statements in the company's annual report.

\subsection{Independent Board of Commissioners}

The commissioner of an organization is a member of the supervisory board. Some specific terms are used to explain the existence or absence of relations with the organization. The Commissioner (or internal commissioner, internal director) is a commissioner who is also an employee, officer, major shareholder, or someone related to the organization (company). Commissioners in representing the interests of shareholders, and sometimes having deep knowledge of performance, finance, mastery of market share of the organization.

External Commissioners (independent commissioners) are members of the board of commissioners who are not employed or people who deal directly with the organization, and do not represent shareholders. An example is 
an appointed commissioner who is currently or has held the position of president of a company from a different industrial sector. The independent commissioner was appointed because his experience was deemed useful for the organization. They can supervise commissioners in and monitor how the organization is run. Independent Commissioners are usually useful in resolving disputes between internal commissioners, or between shareholders and the board of commissioners. The independent commissioner is considered useful because they can be objective and have a small risk of conflict of interest. On the other hand, independent commissioners may lack experience in dealing with specific problems faced by the organization.

The relationship between the proportion of independent board and reaction of stock markets is investigated, where the findings of a study show a positive link between the two (Brickleyet al.,1994). On the other hand, it is noticed that there is no significant relationship between outside directors of a board and firmperformance (Yermack, 1996). Induction of independent directors in corporations is done to improve their performance; therefore, we are expecting a positive effect of board independence on firm value:

\subsection{Factors Affecting Disclosure of Corporate Risk Leverage level}

Leverage that has been used as a proxy for risk related disclosures, in research and findings shows mixed results (Ahn and Lee, 2004 in Amran et al, 2009). Based on the theory of stakeholders, companies are expected to be able to provide risk disclosures in order to provide justification and explanation for what happened at the company. When companies have a higher level of debt risk in the capital structure, creditors can force the company to disclose further information (Ahn and Lee, 2004 in Amran et al, 2009).

Several measures to measure company leverage are debt to equity ratio, debt to asset ratio, debt service coverage, and long term debt to total equity. In this study used debt to asset ratio as an assessment of the level of risk of the company. The debt to asset ratio shows the proportion of a company's assets financed through debt. The greater the debt to asset ratio raises the high level of dependence of companies with creditors (external parties) so that the company may have more financial risks.

Level of Profitability

There is a positive relationship between the level of profitability and risk assessment because company managers can provide greater information to increase investor confidence and thus to increase their compensation (Aljifri and Husainney, 2007). Several measures for calculating the level of profitability include, ROE, ROA and Net Profit Margin. This study uses a net profit (Uyar and Kilic, 2012; Anam et al., 2011; Orens et al., 2009)to measure the level of profitability of a company.

\section{Company Size}

The size of the company can be expressed in total assets, sales and market capitalization. Large companies have many stakeholders, therefore the greater the company, the greater the disclosure of information to meet the needs of stakeholders (Amran et al., 2009) This study uses total assets as a tool for assessing company size. The use of total assets in this study is based on Alsaeed's (2006) research, total assets are proxy of company size found to be significantly associated with the level of voluntary disclosure in Saudi Arabia.

\section{Hypotheses Development}

Based on signaling and agency theory, companies have an incentive to voluntarily disclose further information to investors about risk management in order to signal the quality of underlying risk management to others and to signal that the company is able to protect and create value for investors (Beasley et al., 2005; Connelly et al., 2011). For example, the KNKG guideline CG 20016 states that, "The Board of Directors must develop and implement a company risk management system that covers all aspects of the company's activities" "To ensure proper risk management, the company needs to have a work unit or person in charge of risk control" for companies, investors do not have information about whether company management truly understands the main risks faced by the company.

Thus, providing risk management information to outside parties can help the company management to signify a clear understanding of company risk and therefore increase investor confidence in the company's prospects and performance.

H1 = There Are Positive Effects on Voluntary Disclosure of Risk Management on Firm Values

Previous research on mandatory and discretionary disclosures by public companies provides considerable evidence of the relationship between board characteristics and the level and voluntary quality of disclosures - such as RM disclosures (Cormier et al., 2010; Eng and Mak, 2003). So that the level of monitoring by the board seems to have a significant impact on the intensity and transparency of disclosure (Fama, 1980). Independent commissioners are considered to improve the quality of the board because they are expected to be more impartial shareholder representatives because it is assumed that there is no conflict of interest between owners and agents (Mallin et al., 2005; O'Sullivan, 2000; Ismail and Rahman, 2011; Probohudono et al ., 2013; Sekome and Lemma, 2014). 
The relationship between the ratio of independent board and reaction of stock markets is investigated, where the findings of a study show a positive link between the two (Brickley et al.,1994). On the other hand, it is noticed that there is no significant relationship between outside directors of a board and firmperformance (Yermack, 1996). Induction of independent directors in corporations is done to improve their performance; therefore, we are expecting a positive effect of board independence on firm value:

$H 2$ = There is a Positive Effect the composition of the board of independent commissioners of Firm Value

\section{Research methodology}

\subsection{Sample selection and data source}

The population of the study are Property, Real Estate and Building Construction firm listed on the Bursa Efek Indonesia since 2013. The consideration why we choose the Property, Real Estate and Building Construction Firm because the risk they are facing and the the contribution of the construction sector to national economic growth is partly due to the large allocation of the Government's budget for infrastructure development in the 2017 State Budget, which is Rp. 387.3 trillion or $19 \%$ higher than the 2016 State Budget.

A number of issuers in the construction and infrastructure sectors received good financial performance during the first semester of 2017. The growth of issuers' profit in the construction sector was inseparable from the massive infrastructure development in Indonesia with a fairly expansive development of the property business. The budget for infrastructure continues to increase significantly because the Government places infrastructure development as a fundamental factor to encourage equitable distribution and equitable economic growth.

From total 49 firms selected only 31 firms to testing the hypotheses. The VRMD taken form 2017 annual report and variable control taken form 2016 \& 2017 annual report. The reason why we use one year data of VRMD instead of longitudinal basis is because prior literatures (such as Abraham and Shrives, 2014; Miihkinen, 2013; Zaini, 2014) found that VRMD is not significantly different between years. Based on the content analysis done by Abraham and Shrives (2014), they found risk management disclosure remain unchanged over time, indicating disclosure inertia. Miihkinen (2013) also found the same pattern of risk disclosures from 2006 until 2009. This study uses a purposive sampling method that is the sample is selected based on the availability of information and conformity with the criteria specified in this study.

\section{Measurement of variables and data collection methods 6.1 Dependent variable: Firm Value}

This study utilizes two measurements for FV, that is, market capitalization (MCAP) and Tobin's Q (TOBIN). Some prior studies used share price to measure the value of a firm (including Chakhovich, 2013; Vafaei et al., 2011; Oliveira et al., 2010; Core et al., 2002). However, MCAP has been argued to be more accurate in measuring FV. The reason is, MCAP takes into account the market value of a firm as a whole, while share price only measures the value of a firm based only on the price of one share (Uyar and Kilic, 2012; Anam et al., 2011). We calculate MCAP by multiplying firm's outstanding shares with firm's market price per share.

Hassan et al. (2009) stated that the company's stock price six months after the end of the financial year can ensure that stock prices have captured all accounting information disclosed by the company's annual report. For this study using two dates to ensure that the capture of accounting information is disclosed in the company's annual report as well as economic factors that might influence the company's stock price.

In addition, previous research found that among many macroeconomic factors, changes in world oil prices were one of the factors that did not significantly affect changes in the share of company prices (Apergis and Miller, 2009; Al-Fayoumi, 2009). Therefore, the assumption that the company's share price at the end of six months after the end of the year has been considered all the economic changes that occur during that period and will provide a fair reflection of FV. With regard to the book value of equity, taken at the end of the accounting year. Stock price data comes from the IDX database while other financial data comes from financial statements in the company's annual report.

\subsection{Independent variable: VRMD}

Consistent with Linsley and Shrives (2006), we used content analysis method to collect the data of VRMD. Data was collected from three sections of the narrative parts of the Annual Report, namely, Chairman's Statement (CS), Operations Review (OR) and Management Discussion and Analysis (MD\&A). This study uses the number of "sentences" for the text encoding unit. Past studies (such as Abraham and Cox, 2007; Linsley and Shrives, 2006; Azlan et al., 2009) also used the number of "sentences" as the coding unit in their studies. Linsley and Shrives (2006) suggest, sentences are to be coded as risk disclosure if the reader is informed of any opportunity or prospect, or of any hazard, danger, harm, threat or exposure, that has already impacted upon the firm or may impact upon the firm in the future or of the management of any such opportunity, prospect, hazard, harm, threat or exposure. One (1) mark is to be given to each sentence that contains VRMD. 
Table 1. Risk Category

\begin{tabular}{|l|l|}
\hline \multicolumn{1}{|c|}{ Risk Category } & \multicolumn{1}{|c|}{ Rick Detail } \\
\hline Operational Risk & Customer Satisfaction \\
& Product Development \\
& Efficiency \& Performance \\
& Sourching \\
& Stock Obsolence and Shrinkage \\
& Product and Service Failure \\
& Environmental \\
& Healt \& Safety \\
& Brand name erosion \\
\hline Strategy Risk & Environmental Scan \\
& Industry \\
& Business Protfolio \\
& Competitors \\
& Pricing \\
& Valuation \\
& Planning \\
& Life Cycle \\
& Performance Measures \\
& Regulatory \\
& Sovereign and Political \\
\hline Empowerment Risk & Management and employee fraud \\
IIlegal act \\
\hline Integrity Risk & Reputation \\
& Integrity \\
\hline & Leadership and management \\
& Outsourching \\
& Performance incentive \\
Change readiness \\
Communication \\
\hline & Access \\
& Availability \\
Technology \\
\hline
\end{tabular}

Source: Based on Linsley and Shrives (2006)

\subsection{Independent variable: BOARD}

In particular, independent commissioner are considered to enhance the quality of the board as they are expected to be more unbiased representatives of shareholders due to an assumed absence of conflicts of interest between the principal and the agent (Mallin et al., 2005; O'Sullivan, 2000; Ismail and Rahman, 2011; Probohudono et al., 2013; Sekome and Lemma, 2014). Thus, the greater the number of independent commissioners on the board, the more likely the board will identify relevant risks and promote quality RM disclosures to inform shareholders

\subsection{Control variables}

Based on previous studies, control variables used in this study include firm size, leverage \& proft (Uyar and Kilic, 2012; Anam et al., 2011; Al-Akra and Ali, 2012; Hassan et al., 2009; Orens et al., 2009). Past studies control firm size because large firmoften voluntarily disclose more information to investors (Gul and Leung, 2004; Eng and Mak, 2003) and this facilitates large-sized firms to get more investment. Therefore large firms tend to have a much higher value than small firms (Al-Akra and Ali, 2012). Hassanet al., 2009). Hence, a positive relationship between Firm Size and FV is expected. Prior literature also found that leverage usually has a negative and significant relationship with FV because leverage serves as a proxy for financial risk (Orens et al., 2009; Klein et al., 2005; Chen et al., 2006). In terms of profits, previous studies found profit usually have positive and significant relationship with FV because firms with high profits tend to have high performance and prospects, as well as being less risky (Orens et al., 2009; Chen et al., 2006).

\subsection{Multivariate model}

To test the hypothesis, we use a multivariate model as shown below. 
FVit $=\beta 0 i+\beta 1$ LnFVi $-1+\beta 2$ VRMDit $+\beta 3$ LnSIZEit $+\beta 4$ LEVit $+\beta 5$ LnPROFIT2017it $+\beta 6$ LnPROFIT2016it $+\beta 7$ BOARD $+\varepsilon$

Where:

$\mathrm{FV}=$ is firm value (proxy based on market capitalization (MCAP), Tobin's Q (TOBIN)

$\mathrm{VRMD}=$ Voluntary risk management disclosure

LnSIZE natural logarithm of total assets (Uyar and Kilic, 2012; Chen et al., 2014)

LEV = Total liabilities / total assets (Uyar and Kilic, 2012; Baek et al., 2004)

PROFIT = Natural logarithms of net income (Uyar and Kilic, 2012; Anam et al., 2011; Orens et al., 2009);

BOARD $=$ Proportion of independent board of commissioner

$\mathrm{i}=$ Firma indicator

$\mathrm{t}=$ indicator Year

$\varepsilon=$ standard Error.

\section{7 . Result and Finding}

\subsection{Test Results of Descriptive Statistics}

Data collected for the research is from the financial statements of construction companies listed on the Indonesian Stock Exchange for the 2017 and 2016 reporting periods . Based on the results of the research conducted, the following are the results of recapitulation of data based on descriptive statistics. Independent variables uses in this study consisted of leverage, profitability, and firm size as independent variables, risk management disclosures and the composition of independent commissioners as independent variables, Firm Value represented by Market Capitalization and Tobin's Q as the dependent variable.

Table 2.A shows descriptive statistics for FV variables. It shows an average market capitalization (MCAP) decreases from 2016 to 2017. On the other hand Tobin Q average value shows good performance (mean value $=$ 1). The average value above 1 means that the company's market value exceeds the book value of the assets owned by the company. Based on kurtosis and the slope of MCAP and TOBIN it was found that data from these variables were not normal. Thus, similar to prior studies (such as Uyar and Kilic, 2012; Hassan et al., 2009 and Al-Akra and Ali, 2012), we changed the MCAP and TOBIN variables into natural logarithms (Ln). Descriptive statistics after data transformation are shown in Table 2.B

Table 2.A Descriptive Statistics of Firm Value Variables before transformation

\begin{tabular}{|c|c|c|c|c|c|c|c|c|}
\hline & $\mathrm{N}$ & Minimum & Maximum & Mean & Std. Deviation & Skewness & \multicolumn{2}{|c|}{ Kurtosis } \\
\hline & & Statistic & Statistic & Statistic & Statistic & Std. Error & Statistic & $\begin{array}{l}\text { Std. } \\
\text { Error }\end{array}$ \\
\hline LnMCAPYE & 31 & 58.237 mil & $4.609 .081 \mathrm{mil}$ & $9.875 .726 \mathrm{mil}$ & $0.406 .327 \mathrm{mil}$ & .421 & .788 & .821 \\
\hline LnMCAP6M & 31 & $84.708 \mathrm{mil}$ & $0.121 .079 \mathrm{mil}$ & $8.470 .098 \mathrm{mil}$ & $8.403 .469 \mathrm{mil}$ & .421 & .617 & .821 \\
\hline LnMCAPYEt-1 & 31 & $33.089 \mathrm{mil}$ & $4.613 .451 \mathrm{mil}$ & $0.689 .523 \mathrm{mil}$ & $0.572 .298 \mathrm{mil}$ & .421 & -.369 & .821 \\
\hline LnMCAP6Mt-1 & 31 & 81.399 mil & $5.221 .454 \mathrm{mil}$ & $0.340 .864 \mathrm{mil}$ & $0.256 .433 \mathrm{mil}$ & .421 & -.066 & .821 \\
\hline LnTOBINYE & 31 & 0.09 & 5.28 & 1.03 & 1.01 & .421 & 10.581 & .821 \\
\hline LnTOBINYEt- 1 & 31 & 0.01 & 4.13 & 0.98 & 0.93 & .421 & 5.912 & .821 \\
\hline LnTOBIN6M & 31 & 0.05 & 3.35 & 0.69 & 0.76 & .421 & 5.627 & .821 \\
\hline $\begin{array}{l}\text { LnTOBIN6Mt-1 } \\
\text { Valid N (listwise) }\end{array}$ & 31 & 0.03 & 4.15 & 0.99 & 0.92 & .421 & 6.286 & .821 \\
\hline
\end{tabular}


Table 2.B Descriptive Statistics of variable Firm Value after transformation

\begin{tabular}{|l|r|r|r|r|r|r|r|r|}
\hline & \multicolumn{1}{|c|}{$\mathrm{N}$} & Minimum & Maximum & Mean & Variance & \multicolumn{1}{c|}{$\mathrm{S}$} & \multicolumn{2}{c|}{ Kurtosis } \\
\cline { 2 - 8 } & Statistic & \multicolumn{1}{c|}{ Statistic } & Statistic & Statistic & Statistic & Statistic & Statistic & $\begin{array}{c}\text { Std. } \\
\text { Error }\end{array}$ \\
\hline LnMCAPYE & 31 & 11.0 & 17.4 & 15.385 & 2.160 & -.928 & 1.145 & .821 \\
LnMCAP6M & 31 & 11.34 & 17.22 & 15.3171 & 1.855 & -.896 & .917 & .821 \\
LnMCAPYEt-1 & 31 & 10.4 & 17.4 & 15.380 & 2.693 & -1.076 & 1.218 & .821 \\
LnMCAP6Mt-1 & 31 & 11.3 & 17.4 & 15.421 & 2.223 & -.825 & .331 & .821 \\
LnTOBINYE & 31 & -2.40 & 1.66 & -.2694 & .631 & -.331 & 2.277 & .821 \\
LnTOBIN6M & 31 & -3.01 & 1.20 & -.7887 & .894 & -.156 & .821 & .821 \\
LnTOBIN6Mt-1 & 31 & -3.54 & 1.42 & -.3413 & .806 & -1.176 & 4.848 & .821 \\
LnTOBINYEt-1 & 31 & -4.41 & 1.42 & -.3845 & 1.037 & -1.839 & 7.659 & .821 \\
Valid N (listwise) & 31 & & & & & & & \\
\end{tabular}

Notes: $\mathrm{n}=31$. MCAP, Market capitalization; TOBIN, Tobin's Q; YE, Year end; 6M, six months after year end.

Based on 31 sample of companies from the construction industry, the minimum value of TOBIN is 0.01 with a maximum value of 5.28 and the average value of TOBIN in range 0.69-1.03 means that the company is rated lower than the actual book value. A high TOBIN level indicates that the company is valued by the market higher than the actual value of the company (book value).

Table 3.A shows descriptive statistics for company size, leverage, profitability, and growth. In terms of company size, on average, the sample company is found to have IDR 18.3 trillion of total assets. The average leverage level is 0.4 which indicates that the company has a moderate level of financial risk. The average level of profitability is decreased in 2017 (IDR 652 billion) compared to profit in 2016 (DIR 924 Billion). The composition of the board of commissioners is on average $40 \%$ and the average risk management disclosure is $47 \%$.

Table 3.A Descriptive Statistics of independent variables before transformation

\begin{tabular}{|c|c|c|c|c|c|c|c|c|}
\hline & $\mathrm{N}$ & Minimum & Maximum & Mean & Std. Deviation & Skewness & \multicolumn{2}{|c|}{ Kurtosis } \\
\hline & & Statistic & Statistic & Statistic & Statistic & Statistic & Statistic & $\begin{array}{l}\text { Std. } \\
\text { Error }\end{array}$ \\
\hline FIRM SIZE & 31 & IDR 179 Bio & IDR 97.895 Bio & IDR 18.593 Bio & IDR 21.128 Bio & 2.134 & 5.629 & .821 \\
\hline LEV & 31 & .07 & .79 & .4619 & .17352 & -.070 & -.239 & .821 \\
\hline PROFITYE & 31 & IDR 1 bio & IDR 2.037 Bio & IDR 652 Bio & IDR 569 Bio & .910 & .005 & .821 \\
\hline PROFITYE-1 & 31 & IDR 0,43 Bio & IDR 5.166 Bio & IDR 924 Bio & IDR 1.164 Bio & 2.434 & 6.572 & .821 \\
\hline VRMD & 31 & .62 & .4745 & .01299 & .005 & .091 & -.741 & .821 \\
\hline BOARD & 31 & .160 & .800 & .40445 & .120850 & 1.228 & 3.320 & .821 \\
\hline $\begin{array}{l}\text { Valid N } \\
\text { (listwise) }\end{array}$ & 31 & & & & & & & \\
\hline
\end{tabular}

Table 3.B Descriptive Statistics of independent variables after transformation

\begin{tabular}{|l|r|r|r|r|r|r|r|r|}
\hline & \multicolumn{1}{|c|}{$\mathrm{N}$} & \multicolumn{1}{c|}{ Minimum } & Maximum & \multicolumn{1}{c|}{ Mean } & Variance & \multicolumn{1}{c|}{$\mathrm{S}$} & \multicolumn{2}{c|}{ Kurtosis } \\
\cline { 2 - 8 } & Statistic & \multicolumn{1}{c|}{ Statistic } & \multicolumn{1}{c|}{ Statistic } & Statistic & Statistic & Statistic & Statistic & $\begin{array}{c}\text { Std. } \\
\text { Error }\end{array}$ \\
\hline FIRM SIZE & 31 & 12.1 & 18.4 & 16.087 & 1.770 & -.814 & 1.326 & .821 \\
LEV & 31 & .07 & .79 & .4619 & .030 & -.070 & -.239 & .821 \\
PROFITYE & 31 & 7.0 & 14.5 & 12.652 & 3.235 & -1.948 & 4.053 & .821 \\
PROFITYE-1 & 31 & 6.1 & 15.5 & 12.798 & 3.632 & -1.703 & 4.155 & .821 \\
VRMD & 31 & .34 & .62 & .4745 & .005 & .091 & -.741 & .821 \\
BOARD & 31 & .17 & .80 & .4052 & .014 & 1.286 & 3.372 & .821 \\
Valid N (listwise) & 31 & & & & & & & \\
\end{tabular}




\subsection{Multicollinearity Test Results}

Table 4.A shows the results of the Pearson correlation test for VRMD, LnMCAP and LnTOBIN. LnSIZE and PROFIT show that there is no multicollinearity between independent variables because almost all variables have correlations below 0.9 (Gujarati and Porter, 2009).

Tabel 4.A

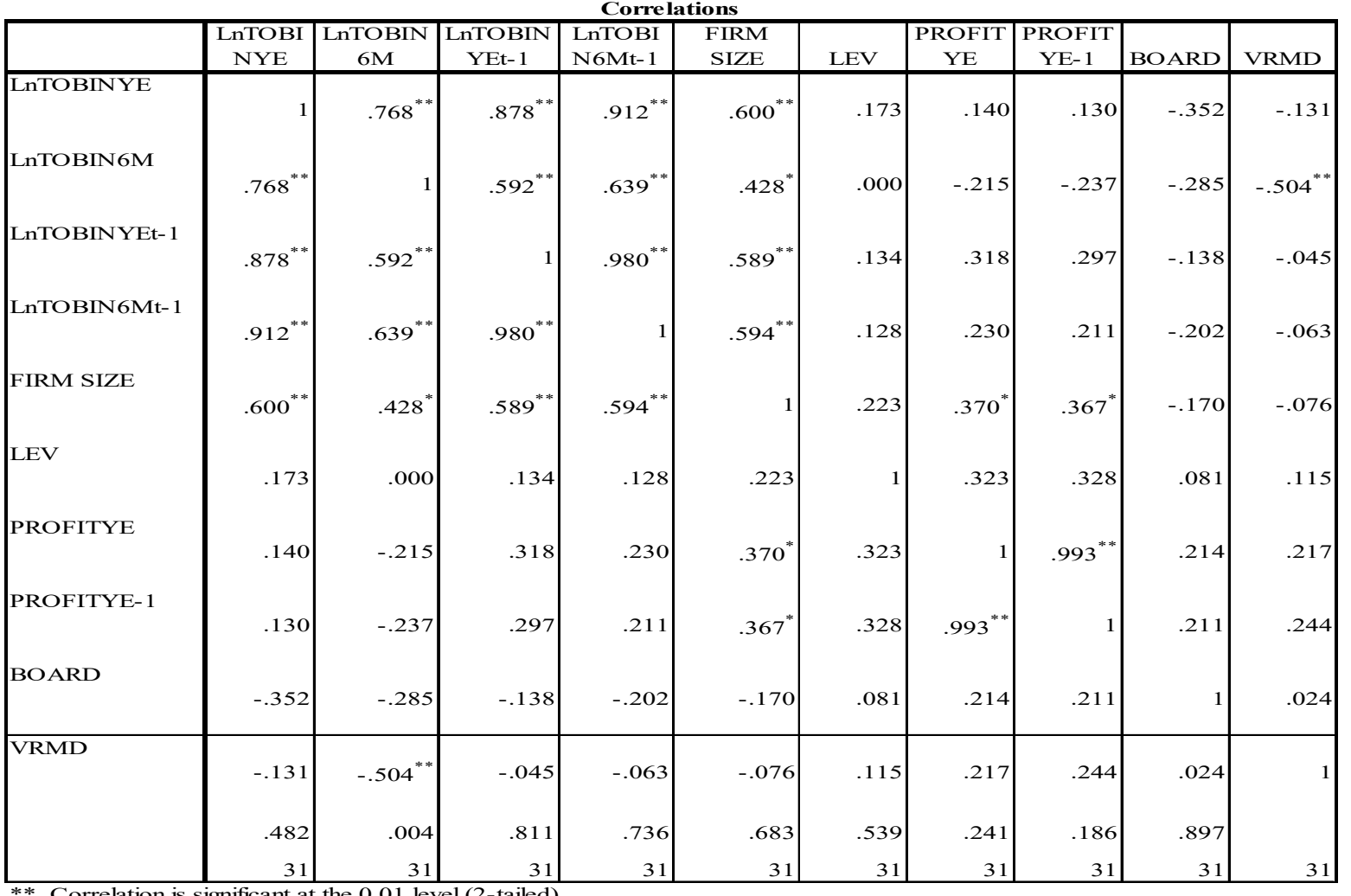

*. Correlation is significant at the 0.05 level (2-tailed).

Tabel 4.B

\begin{tabular}{|c|c|c|c|c|c|c|c|c|c|c|}
\hline & $\begin{array}{l}\text { FIRM } \\
\text { SIZE }\end{array}$ & LEV & $\begin{array}{c}\text { PROFIT } \\
\text { YE }\end{array}$ & \begin{tabular}{|c|} 
PROFIT \\
YE-1
\end{tabular} & BOARD & VRMD & \begin{tabular}{|c|} 
LnMCAP \\
YE
\end{tabular} & $\begin{array}{c}\text { LnMCAP } \\
6 \mathrm{M}\end{array}$ & \begin{tabular}{|c|} 
LnMCAP \\
YEt-1
\end{tabular} & $\begin{array}{c}\text { LnMCAP } \\
6 \mathrm{Mt}-1\end{array}$ \\
\hline FIRM SIZE & 1 & .223 & $.370^{*}$ & $.367^{*}$ & -.170 & -.076 & $.600^{* * *}$ & $.617^{* *}$ & $.593^{* *}$ & $.612^{* *}$ \\
\hline LEV & .223 & 1 & .323 & .328 & .081 & .115 & .306 & .318 & .305 & .316 \\
\hline PROFITYE & $.370^{*}$ & .323 & 1 & $.993^{* *}$ & .214 & .217 & $.808^{* * *}$ & $.823^{* *}$ & $.843^{* *}$ & $.838^{* *}$ \\
\hline PROFITYE-1 & $.367^{*}$ & .328 & $.993^{* *}$ & 1 & .211 & .244 & $.801^{* *}$ & $.815^{\star *}$ & $.838^{* *}$ & $.834^{* \star}$ \\
\hline BOARD & -.170 & .081 & .214 & .211 & 1 & .024 & .154 & .134 & .144 & .130 \\
\hline VRMD & -.076 & .115 & .217 & .244 & .024 & 1 & -.115 & -.114 & -.094 & -.076 \\
\hline LnMCAPYE & $.600^{* *}$ & .306 & $.808^{* *}$ & $.801^{* *}$ & .154 & -.115 & 1 & $.994^{* *}$ & $.990^{\star *}$ & $.988^{* *}$ \\
\hline LnMCAP6M & $.617^{* *}$ & .318 & $.823^{* *}$ & $.815^{* *}$ & .134 & -.114 & $.994^{* *}$ & 1 & $.987^{* *}$ & $.987^{* *}$ \\
\hline LnMCAPYEt-1 & $.593^{* *}$ & .305 & $.843^{* *}$ & $.838^{* *}$ & .144 & -.094 & $.990^{* *}$ & $.987^{* *}$ & 1 & $.993^{* *}$ \\
\hline LnMCAP6Mt-1 & $.612^{* *}$ & .316 & $.838^{* *}$ & $.834^{* *}$ & .130 & -.076 & $.988^{* * t}$ & $.987^{* *}$ & $.993^{* *}$ & 1 \\
\hline
\end{tabular}




\subsection{Hypotesis Result}

From table 5.A and table 5.B, the results of VRMD are negative and significant related to FV on both proxy Tobin's Q and MCAP thus H1 is not accepted, similar with the test results between BOARD and FV show results that are not significant so $\mathrm{H} 2$ is not accepted. While other independent variable shows that firm size has a positive relationship with FV on both proxy either Tobin's Q and MCAP. The finding from ERM disclosure of the property, real estate and building construction industry stated that the most influence factor of their risk is the unstable economic conditions the upcoming political year in 2018 and 2019. In this uncertain economic situation investors are waiting better economic situation and stable politic environment. While on control variables, only Firm Size has positive significant effect toward Firm Value, this result is in line with has expected.

\section{Tabel 5.A Multiple Regresion for TOBIN'Q}

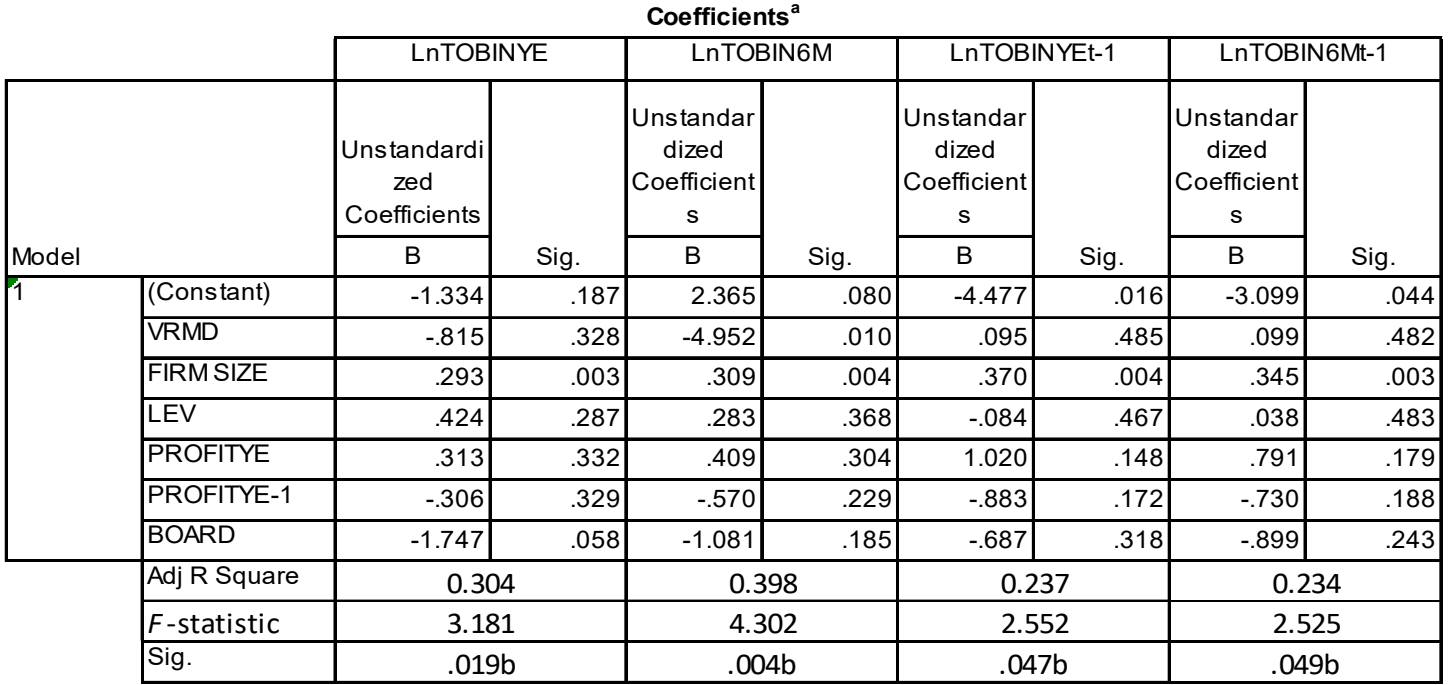

Tabel 5.B Multiple Regresion for MCAP

\begin{tabular}{|c|c|c|c|c|c|c|c|c|c|}
\hline \multicolumn{10}{|c|}{ Coefficients $^{\mathrm{a}}$} \\
\hline & & \multicolumn{2}{|c|}{ LnMCAPYE } & \multicolumn{2}{|c|}{ LnMCAP6M } & \multicolumn{2}{|c|}{ LnMCAPYEt-1 } & \multicolumn{2}{|c|}{ LnMCAP6Mt-1 } \\
\hline \multirow{2}{*}{\multicolumn{2}{|c|}{ Model }} & $\begin{array}{c}\text { Unstandardi } \\
\text { zed } \\
\text { Coefficients }\end{array}$ & \multirow[b]{2}{*}{ Sig. } & \begin{tabular}{|c|} 
Unstandar \\
dized \\
Coefficient \\
s
\end{tabular} & \multirow[b]{2}{*}{ Sig. } & \begin{tabular}{|c|} 
Unstandar \\
dized \\
Coefficient \\
s
\end{tabular} & \multirow[b]{2}{*}{ Sig. } & \begin{tabular}{|c|} 
Unstandar \\
dized \\
Coefficient \\
s
\end{tabular} & \multirow[b]{2}{*}{ Sig. } \\
\hline & & B & & B & & B & & B & \\
\hline \multirow[t]{7}{*}{1} & (Constant) & 4.914 & .002 & 5.409 & .000 & 3.177 & .023 & 4.263 & .003 \\
\hline & \begin{tabular}{|l|} 
VRMD \\
\end{tabular} & -5.428 & .004 & -5.030 & .002 & -5.921 & .002 & -4.901 & .004 \\
\hline & FIRM SIZE & .320 & .002 & .301 & .001 & .324 & .002 & .321 & .001 \\
\hline & LEV & .197 & .401 & .250 & .353 & .113 & .442 & .182 & .399 \\
\hline & PROFITYE & .246 & .371 & .315 & .309 & .243 & .371 & .175 & .398 \\
\hline & PROFITYE-1 & .451 & .265 & .349 & .283 & .591 & .203 & .560 & \begin{tabular}{ll|}
.197 & \\
\end{tabular} \\
\hline & BOARD & .691 & .270 & .378 & .345 & .416 & .354 & .308 & .382 \\
\hline & Adj R Square & \multicolumn{2}{|c|}{0.781} & \multicolumn{2}{|c|}{0.818} & \multicolumn{2}{|c|}{0.829} & \multicolumn{2}{|c|}{0.823} \\
\hline & F-statistic & \multicolumn{2}{|c|}{18.796} & \multicolumn{2}{|c|}{23.480} & \multicolumn{2}{|c|}{25.274} & \multicolumn{2}{|c|}{24.246} \\
\hline & Sig. & \multicolumn{2}{|c|}{$.000 \mathrm{~b}$} & \multicolumn{2}{|c|}{$.000 \mathrm{~b}$} & \multicolumn{2}{|c|}{$.000 \mathrm{~b}$} & \multicolumn{2}{|c|}{$.000 \mathrm{~b}$} \\
\hline
\end{tabular}

The findings might be different if the sample industry were more than one industry, we suggest that the results of this study can be caused by unbalance disclosure of negative risk management disclosures or 'bad news' than positive risk management disclosures or 'good news'. This findings supported by prior empirical studies such as Ajinkya and Gift (1984) and Rikhardsson and Holm (2008) found disclosing bad news give negative effects to the firm, where Ajinkya and Gift (1984) found that disclosing bad news is associated with a downward price revision; and Rikhardsson and Holm (2008) found that stock returns react negatively to negative environmental news.

\section{Discussion and conclusion}

This study examined the effects of VRMD on FV. Univariate results and multivariate tests show that VRMD tends to be negative and significantly related to FV. Our findings support the signaling theory in that argument VRMD 
can influence FV and also support the previous literature argument about the importance of disclosing potential risks and prospect information that will provide the right signal and hence can help investors make better decisions about their investment in the company (Linsley and Shrives, 2006; Beretta and Bozzolan, 2004; Cabedo and Tirado, 2004; Solomon et al., 2000).

The proportion of the Independent Board of Commissioners does not show a significant effect on Company Values, however this study is limited to only the proportion of the number of board of commissioners regardless of the level of expertise possessed by each board of commissioners. Further research needs to be done on the characteristics of the board of commissioners that influence the increase on Firm Value.

\section{Limitation and Future Research}

Levels of risk management disclosure at a moderate level indicate that the company's awareness of the risks faced by the company in the future increases sufficient levels, but because companies engaged in the property, real estate and building construction sector are very dependent on how companies can identify opportunities and risks in their operations, the disclosure of risk management suggested would be increased to the minimum high level The research conducted by Maizatulakma Abdullah, Zaleha Abdul Shukor, Zakiah Muhammadun Mohamed, Azlina Ahmad, (2015) Risk management disclosure: A study of the effect of voluntary risk management disclosures on company value, separating risk management disclosures that are "good news" and "bad news ", So it can be more clearly examined the types of disclosures that should be disclosed in the company's annual report. Therefore, the researcher suggests for further research the risk management disclosure category of companies is divided into two categories, namely risk management disclosures which are good news and risk management disclosures that is not good news.

Independent board of commissioners in this study shows insignificant results related to Firm Values, in this study the researcher did not include the expertise variables of each member of the independent board of commissioners as a variable that affects the value of the Company. It is expected that further research can include another corporate governance variables such as the proportion of independent director and the expertise in accounting of independent director so that it can become a clearer reference for companies in determining board members who can provide value added to the company.

\section{Reference}

Abraham, S. and Shrives, P.J. (2014), "Improving the relevance of risk factor disclosure incorporate annual reports", The British Accounting Review, Vol. 46 No. 1, pp. 91-107.31 No. 5,pp. 533-549.

Ajinkya, B.B. and Gift, M.J. (1984),“Managers' earnings forecasts and symmetrical adjustments of market expectations", Journal of Accounting Research, Vol. 22 No. 2 ,

pp. 425-444

Al-Fayoumi, N. (2009), "Oil prices and stock market returns in oil importing countries: the case of Turkey, Tunisia and Jordan”, European Journal of Economics, Finance and Administrative Sciences, Vol. 16 No. 2, pp. 86101.

Al-Akra, M. and Ali, M. (2012), "The value relevance of corporate voluntary disclosure in the middle-east: the case of Jordan", Journal of Accounting and Public Policy, Vol. 31 No. 5,pp. 533-549

Amir, E. and Lev, B. (1996), "Value-relevance of nonfinancial information: the wireless communications industry", Journal of Accounting and Economics, Vol. 22 Nos 1-3, pp. 3-30.

Amran, N.A. and Ahmad, A.C. (2009),"Family business, board dynamics, and firm value: evidence from Malaysia", Journal of Financial Reporting and Accounting, Vol. 7 No. 1,pp. 53-74.

Apergis, N. and Miller, S. (2009), “Do structural oil-market shocks affect stock prices?”, Energy Economics, Vol. 31 No. 4, pp. 569-575

Badan Pusat Statistik, Statistik Indonesia 2017

Beattie, V., McInnes, B. and Fearnley, S. (2004), "A methodology for analyzing and evaluating narratives in annual reports: a comprehensive descriptive profile and metrics for disclosure quality attributes", Accounting Forum, Vol. 28 No. 3, pp. 205-23

Bokpin, G.A. (2013),"Determinants and value relevance of corporate disclosure: evidence fromthe emerging capital market of Ghana”, Journal of Applied Accounting Research, Vol. 14 No. 2, pp. 127-146.

Brickley J.A et al. (1997) "Leadership structure: Separating the CEO and Chairman of the Board " Journal of Corporate Finance 3 189-220

Cabedo, J.D. and Tirado, J.M. (2004), “The disclosure of risks in financial statements”, Accounting Forum, Vol. 28 No. 1, pp. 181-200.

CRMS Indonesia, Survey Nasional Manajemen Risiko 2016

CRMS Indonesia, Survey Nasional Manajemen Risiko 2017

CRMS Indonesia, Survey Nasional Manajemen Risiko 2018

Cabedo, J.D. and Tirado, J.M. (2004), “The disclosure of risks in financial statements”, Accounting Forum, Vol. 
28 No. 1, pp. 181-200.

Fama, E.F. (1980), “Agency problems and the theory of the firm”,Journal of Political Economy,Vol. 88 No. 2, pp. 288-307.

Gujarati, D.N. and Porter (2009),Basic Econometrics, McGraw-Hill, New York, NY.

Hassan, O.A.G., Romilly, P., Giorgioni, G. and Power, D. (2009), "The value relevance of disclosure: evidence from the emerging capital market of Egypt", The International Journal of Accounting, Vol. 44 No. 1, pp. 124.

Healy, P.M. and Palepu, K.G. (2001), "Information asymmetry, corporate disclosure and the capital markets: a review of empirical disclosure literature", Journal of Accounting and Economics, Vol. 31 Nos 1-3, pp. 405440.

Komite Nasional Kebijakan Governance Pedoman CG 2006

Kalim Ullah Bhat, Yan Chen, Khalil Jebran, Niaz Ahmed Bhutto, (2018) "Corporate governance and firm value: acomparative analysis of state and non-state owned companies in the context of Pakistan", Corporate Governance: The International Journal of Business in Society, Vol. 18 Issue: 6, pp.1196-1206,

Linsley, P.M. and Shrives, P.J. (2006), "Risk reporting: a study of risk disclosure in the annual report of UK firms", The British Accounting Review, Vol. 38 No. 4, pp. 387-404.

Lajili, K. and Zeghal, D. (2005), "A content analysis of risk management disclosures in Canadian annual reports", Canadian Journal of Administrative Sciences, Vol. 22 No. 2, pp. 125-142.

Maizatulakma Abdullah, Zaleha Abdul Shukor, Zakiah Muhammadun Mohamed, Azlina Ahmad, (2015) "Risk management disclosure: A study on the effect of voluntary risk management disclosure toward firm value". Journal of Applied Accounting Research, Vol. 16 Issue: 3, pp.400-432

Miihkinen, A. (2013), “The usefulness of firm risk disclosures under different firm riskiness, investor-interest, and market conditions: new evidence from Finland", Advances in Accounting, Vol. 29 No. 2, pp. 312-331.

Minna Yu, Ronald Zhao, (2015) "Sustainability and firm valuation: an international investigation", International Journal of Accounting and Information Management, Vol. 23 Issue: 3, pp.289-307

Ohlson, J.A. (1995), “Earnings, book values, and dividends in equity valuation”, Contemporary Accounting Research, Vol. 11 No. 2, pp. 661-687.

Orens, R. and Lybaert, N. (2007), "Does the financial analysts' usage of non-financial information influence the analysts' forecast accuracy? Some evidence from the Belgian sell-side financial analyst", The International Journal of Accounting, Vol. 42 No. 3, pp. 237-271.

National Strategic Project "Acceleration Committee Provision of Priority Infrastructure (KPPIP), https: // kppip.go.id/en/national-strategic-projects.

Rikhardsson, P. and Holm, C. (2008),"The effect of environmental information on investment allocation decisions-an experimental study", Business Strategy and the Environment, Vol. 17 No. 6, pp. 382-397.

Sherrena Buckby, Gerry Gallery, Jiacheng Ma, (2015) "An analysis of risk management disclosures: Australian evidence", Managerial Auditing Journal, Vol. 30 Issue: 8/9, pp.812-869

Skinner, D.J. (1994),“Why firms voluntarily disclose bad news”, Journal of Accounting Research,Vol. 32 No. 1, pp. 38-60.

Solomon, J.F., Solomon, A., Norton, S.D. and Joseph, N.L. (2011), "Private climate change reporting: an emerging discourse of risk and opportunity?", Accounting, Auditing \& Accountability Journal, Vol. 24 No. 8, pp. 11191148 .

Suwardjono. (2005). Accounting Theory: Financial Reporting Engineering, Edition Third. Yogyakarta: BPFE

Uyar, A. and Kilic, M. (2012),"Value relevance of voluntary disclosure: evidence from Turkish firms", Journal of Intellectual Capital, Vol. 13 No. 3, pp. 363-376

Wang, Z., Ali, J.M. and Al-Akra, M. (2013), "Value relevance of voluntary disclosure and the global financial crisis: evidence from China”, Managerial Auditing Journal, Vol. 28 No. 5,pp. 444-468.

Yermack, David, Corporate Governance and Blockchains (December 2015). NBER Working Paper No. w21802. 